\title{
Introducing Prof. Shaun McCann, Bone Marrow Transplantation's New Sommelier
}

\author{
Robert Peter Gale (i] ${ }^{1}$
}

Received: 16 January 2018 / Accepted: 17 January 2018 / Published online: 4 May 2018

c) Macmillan Publishers Limited, part of Springer Nature 2018

His blood, the blood of the grape, lightens the burden of our mortal misery. When, after their daily toils, men drink their fill, sleep comes to them, bringing release from all their troubles. There is no other cure for sorrow. Though himself a God, it is his blood we pour out to offer thanks to the Gods. And through him, we are blessed.

\section{Euripides on Dionysus}

In this issue of Bone Marrow Transplantion we begin a quarterly column on wine and haematology by Prof. Shaun McCann AKA Giovanni Morelli. Why?

Many readers will be aware of the close relationship between bone marrow, blood and wine. About 40 years ago I received an award from the Excerpta Medica Foundation for work in Bone Marrow Transplantation. The ceremony was at the Amstel Hotel in Amsterdam and the presenter, Sir Gordon Wolstenholme OBE. Sir Gordon lead the British Red Cross during WWII and went on to head the Ciba (now Novartis) Foundation. He was also President of the Royal Society of Medicine and the Worshipful Society of Apothecaries. He regaled us with fascinating stories of giving blood transfusions to captured German officers during the war. In the final moments, he said: 'It now falls to me to give this award for advances in bone marrow transplantation. I admit knowing little about bone marrow save it's excellent on toast and goes very well with sherry.'

The French neurologist and polymath Charles-Édouard Brown-Séquard FRS also had a thing for bone marrow. At a time when chlorois (iron deficiency anaemia) was common in Paris he prescribed calf's bone marrow dissolved in

Robert Peter Gale

robertpetergale@gmail.com

1 Haematology Research Centre, Division of Experimental Medicine, Department of Medicine, Imperial College London, London, UK glycerol to be taken by mouth. His notion was he was doing a bone marrow transplant. Nevertheless, his patients, typically young females, recovered rapidly from the haemoglobin-bound iron released by the glycerol. ${ }^{1}$ So much for who did the 1st bone marrow transplant.

Sir Gordon was not alone in his praise of bone marrow. When celebrity chefs were asked what they would choose as their last meal, Anthony Bourdain described scooping rich, buttery marrow out of veal bones, spreading it on a crusty baguette, topping it with a zesty parsley salad accompanied by a good Bordeaux wine. Prof. John Goldman also loved bone marrow on toast. We would often go to St. John Bar and Restaurant Smithfield at the site of the old London meat market which served Fergus Henderson's famed roasted bone marrow (Fig. 1). The question we

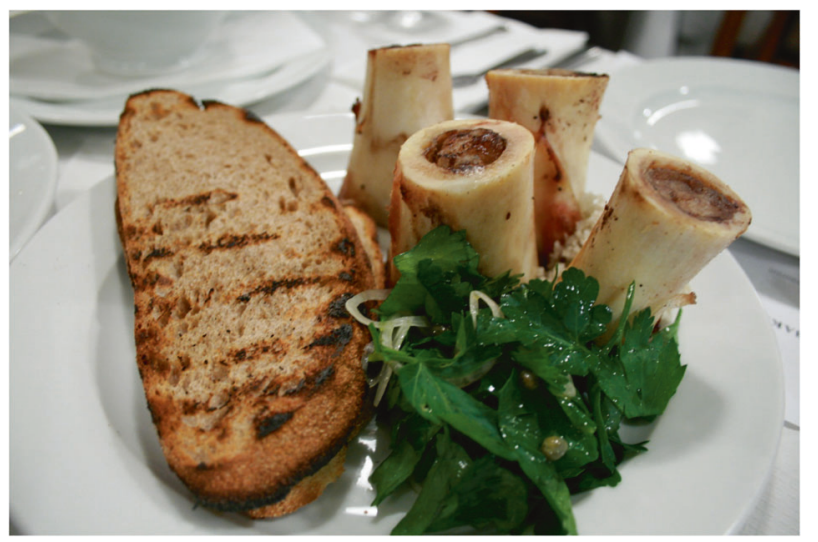

Fig. 1 Dinner at St. John Restaurant and Bar Smithfield with Prof. John Goldman

\footnotetext{
${ }^{1}$ In 1554, German physician Johannes Lange described the condition as 'peculiar to virgins'. He prescribed sufferers should 'live with men and copulate. If they conceive, they will recover.' The name 'chlorosis' was coined in 1615 by Montpellier professor of medicine Jean Varandal from the word 'chloris' (Greek: $\chi \lambda \omega \rho \iota \varsigma)$ meaning 'greenish-yellow', 'pale green', 'pale', 'pallid' or 'fresh'. Both Lange and Varande claimed Hippocrates as a reference.
} 


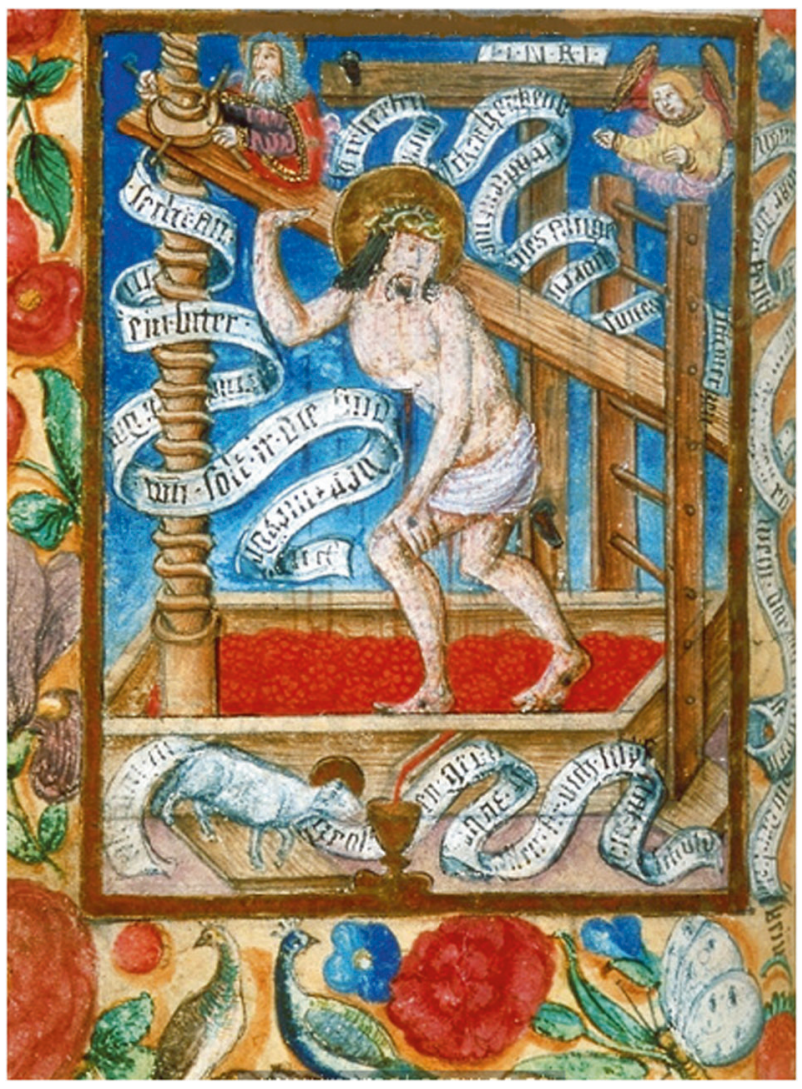

Fig. 2 Prayer-book of 1515-1520. (Gebetbuch Ulrich von Montfort Christus in der Kelter ÖNB cod 2748 fol 49v.jpg; Wikimedia Commons; http://www.imareal.oeaw.ac.at/)

typically pondered: wine or sherry and, if wine, which? Novices, we often went with the house red (coincidentally the least pricey).

There are many other examples. When I queried Google for wine suggestions with bone marrow I got a range of suggestions: Cabernet sauvignon/Bordeaux blend, (especially from Bordeaux), Syrah from the Rhone Valley (especially Cotes du Rhone or Crozes Hermitages (Cornas, if you can find one)), Mourvedre, Aglianico, Brunello di Montalcino and Nero d'Avola. Champagne of course. And this is precisely where Prof, Shaun McCann fits in. How are most of us to know which wine to choose?
For those preferring blood cells to bone marrow there is a nearly universal association between wine and blood in most cultures including Greek, Roman, Scythian, Slavic, African and Judeo-Christian. Typically, wine is used to symbolize blood in religious traditions and ceremonies; a metaphorical leap. For example, Moses sealed his contract of deliverance with sacrificial blood. In the Holy Communion wine symbolizes Christ's blood and in many medieval paintings Christ is shown being crushed like a grape in a wine press with the blood of salvation pouring into the uplifted cups of the believers (Fig. 2). And for those of a secular bend there is the recent album by the British rock group New Model Army: Between Wine and Blood.

Shaun McCann will be well-known to readers of the Journal. He is Professor Emeritus of Haematology and Academic Medicine, St James' Hospital and Trinity College Dublin, served on our Editorial Board for several years and was Medical Director of the Ireland Blood Transfusion Services. Shaun contributes a monthly article on wine to the Irish Medical Times under his nom de plume. He has authoured more than 100 scientific articles and a number of books: An Immodest Proposal-Wine and Health and A History of Haematology: from Herodotus to HIV.

So, put your fears aside and relax. The next time you are out to dinner and about to dive into a plate of roasted bone marrow, blood sausages, black pudding, Polish czarnina, Scandinavian blodplattar or Taiwanese pig's blood cake you can skip the restaurant's sommelier who is likely to suggest a pricey bottle. Simply open the Bone Marrow Transplantation app on your smartphone and call up the recommendation of Prof. Shaun McCann, our official sommelier. He is also available 24/7 (the man never sleeps) on Twitter, Facebook and Instagram, but not Match.com nor 23 and $\mathrm{Me}$, for more complex consultations.

Acknowledgements I acknowledge support from the National Institute of Health Research (NIHR) Biomedical Research Centre funding scheme.

\section{Compliance with ethical standards}

Conflict of interest RPG is a part time employee of Celgene Corp. 